\title{
In Vitro Responses of Alfalfa Root (Medicago Sativa L.) to Salt stress and Melatonin
}

\section{Shabnam Jalili}

University of Isfahan

Ali Akbar Ehsanpour ( $\nabla$ aliakbarehsanpour2@gmail.com )

University of Isfahan

\section{Research Article}

Keywords: IAA, Medicago sativa, Melatonin, salt stress, tissue culture

Posted Date: April 7th, 2021

DOI: https://doi.org/10.21203/rs.3.rs-328300/v1

License: (c) (i) This work is licensed under a Creative Commons Attribution 4.0 International License. Read Full License 


\section{Abstract}

Alfalfa (Medicago sativa L.) is the most cultivated forage legume. The growth and development of alfalfa roots are limited by salt stress. Growth regulator is an essential role of melatonin in plants, especially in root involved in stress tolerance. In this study, alfalfa roots under in vitro salt stress $(150$ and $200 \mathrm{mM} \mathrm{NaCl})$ were pretreated with different concentrations of melatonin $(0.1,10$ and $15 \mu \mathrm{M})$. principal component analysis to find out the best targets for melatonin and salinity. Exogenous utilization of melatonin in alfalfa roots significantly elevated the compatible solutes particularly glycin betaein (GB), soluble carbohydrate and $\mathrm{K}^{+}$content. Principal component analysis revealed that, Indol acetic acid (IAA) content, GB, flavonoids, carbohydrate and $\mathrm{Na}^{+}$were the best melatonin targets. Furthermore, salinity affected $\mathrm{ROS}, \mathrm{H}_{2} \mathrm{O}_{2}, \mathrm{O}^{2-}$, malondialdehyde_(MDA), phenylalanine ammonia-lyase (PAL), $\mathrm{K}^{+} / \mathrm{Na}^{+}$ratio and tyrosine ammonia-lyase (TAL) enzymes were augmented, and electrolyte leakage, $\mathrm{Na}^{+}$accumulation decreased in the saline medium.

\section{Introduction:}

Salt stress limits the growth of plants that are sensitive to salinity and it's determined by combination of soluble salts in the root zone, and the destructive effects of salinity on root growth are associated with oxidative damage, Na toxicity and metabolic disturbance (Munns and Tester 2008). When plants are subjected to high salt concentrations all main physiological processes of growth and development including germination, root growth and crop yields are affected (Parida and Das 2005). The ability of plants to salinity tolerance is usually evaluated in terms of biomass production, ion compartmentalization, induction of antioxidant enzymes activities and osmotic adjustment (Munns and Tester 2008). Increasing salt tolerance of agricultural crops is essential and plant biotechnology can be used as a tool for understanding cellular mechanisms of stress tolerance.

Alfalfa is a perennial flowering legume in the Fabaceae family. It is widely cultivated as an important crop in many countries for various reasons such as soil improvement, animal feed, and due to high concentrations of flavonoids in its foliage, it has medicinal uses (kumar 2011). But soil salinity remains a significant environmental factor limiting yield in all alfalfa varieties. Bhattarai reported that, several alfalfa populations under salt stress treated by different kinds of salt that, root mass per plant at $18.3 \mathrm{dS} \mathrm{m}^{-1}$ and $24.5 \mathrm{dS} \mathrm{m}^{-1}$ EC was decreased by $18 \%$ and $49 \%$ (Bhattarai et al. 2020).

Melatonin as an indoleamine is produced in the plant and has been extensively observed at different concentrations from picograms to micrograms per gram of tissue (Tan et al. 2012). It has been demonstrated to play significant roles in the stress defense. Additionally, melatonin has antioxidant activity, possessing great in vitro and in vivo properties as ROS scavenger (Murch et al. 2000). The same as auxin, Tryptophan is the precursor of melatonin in plants (Arnao and Hernández-Ruiz 2015; Arnao and Hernández-Ruiz 2018). Exogenous melatonin as a growth-stimulating molecule has an auxin-like role and was observed to improve plant roots under salt stress. Arnao and Hernández-Ruiz reported that melatonin induced a 3 to 4-fold rise in plant development and growth in the aerial parts as well as roots compared with control plants (Arnao and HernándezRuiz 2018). Moreover, the growth-promoting effects of melatonin under salt stress has been shown in Helianthus (Mukherjee et al. 2014), Cucumbers (Wang et al. 2015) and Zea mays (Kim et al. 2016), and to cold stress in Cynodon (Shi et al. 2015). Researches have shown that melatonin by a dose-dependent manner resembling to IAA affect root growth. Lateral root growth is stimulated at low concentrations, while at high concentrations, adventitious root structure happens and lateral root formation is prevented in a pathway independent of auxin (Weeda et al. 2014). Melatonin has the effect on root growth or regeneration of adventitious and lateral roots in Arabidopsis, Prunus, Brassica, Oryza, and Lupinus [hardeland]. Melatonin has a positive influence on rooting at low concentration however, a growth inhibitory effect at high concentrations in sweet cherry (Sarropoulou et al. 2012). Moreover, exogenous melatonin had a specific impact on the root number and diameter but did not affect root length in cucumber (Zhang et al. 2013). The relationship between melatonin treatment and endogenous IAA levels remains controversial. For instance, melatonin treatment increase in endogenous IAA in Brassica juncea (Chen et al. 2009) but it reduces IAA levels in tomato by 7 folds and 1.4 fold in Arabidopsis (Zuo et al. 2014). Melatonin as a regulator of growth and detoxifies hydroxyl radical, nitric oxide and superoxide anion can alleviate the effects of salinity stress by 
regulating phenolic content, carbohydrate metabolism, compatible osmolytes and lipid biosynthesis under environmental stress (Arnao and Hernández-Ruiz 2014). Melatonin may be effective as a first line defensive factor against ROS production under stress conditions (Tan et al. 2002). The phenylpropanoid pathway is one of the critical signaling pathways for producing many important compounds, such as phenols, flavonoids and anthocyanin (Pourcel et al. 2007). phenylalanine ammonia-lyase (PAL) and tyrosine ammonia-lyase (TAL) are the key enzymes in the phenylpropanoid pathway. The relationship between activity of TAL and PAL in roots treated with melatonin under salt stress has not been well understood. This study, presents evidence for significant dissection of the regulatory mechanism and physiological function of melatonin-mediated salt tolerance. Understanding of root responses of alfalfa could bring a novel conception into melatonin function in root plants using in vitro tissue culture technology.

\section{Materials And Methods:}

\section{Plant material and culture conditions:}

Seeds of Medicago sativa cv. Isfahani from the Pakan Bazr Company in Isfahan, Iran was used for this research. Alfalfa seeds were surface-sterilized with 70\% (v/v) ethanol for 1 min then 10\% (v/v) bleach for 20 min and washed three times with sterile distilled water. Seeds then were germinated in sterile (MS) (Murashige and Skoog 1962) medium adjusted pH of 5.8, supplemented with filter-sterilized melatonin from solarbio life sciences, Beijing, China $(0,0.1,10,15 \mu \mathrm{M})$, and $\mathrm{NaCl}(150,200$ $\mathrm{mM})$. Medium without melatonin and $\mathrm{NaCl}$ used as control. All cultures were transferred to the culture room ( $25 \pm 1 \circ \mathrm{C}$ under 16/8 $\mathrm{h}\left(44 \mu \mathrm{mol}\right.$ phot. $\left.\mathrm{m}^{-2} \mathrm{~s}^{-1}\right)$ light /dark photoperiod. After 10 days, physiological and biochemical factors were measured.

\section{Measurement of Growth Factors:}

Lateral Root Number, Root length and fresh weight (FW) of the roots were estimated after 10 days. For measuring dry weight, samples were dry at $70^{\circ} \mathrm{C}$ for $24 \mathrm{~h}$.

\section{Determination of Soluble Carbohydrates Content:}

Dubois method was used for determining of Soluble carbohydrates (1956). Dry root was homogenized by deionized water. The extracts mixed with $0.5 \mathrm{~mL}$ of phenol (5\%) and $2.5 \mathrm{~mL}$ sulfuric acid (96\%). This mixture was vortexed and absorbance was recorded at $490 \mathrm{~nm}$ (Synergy HTX multi-mode reader, BioTek, USA) after $30 \mathrm{~min}$.

\section{Determination of Total Anthocyanin Content:}

Total anthocyanin was measured based on Wagner (Wagner 1979) method with a slight modification. Fresh roots were grinded in acidified methanol solution and incubated in dark place for $24 \mathrm{~h}$. Samples were centrifuged for 10 min at 4000 $\mathrm{rpm}$ and the absorbance of the supernatant was measured at $550 \mathrm{~nm}$. The anthocyanin content measured by extinction coefficient $\left(33000 \mathrm{M}^{-1} \mathrm{~cm}^{-1}\right)$ and results were reported as $\mu \mathrm{mol} . \mathrm{g}^{-1} \mathrm{FW}$.

\section{Determination of Total Phenolic Content:}

The Folin-Ciocalteu test was determined total phenolic content (Singleton et al. 1999). $0.5 \mathrm{~mL}$ methanolic extract of the root was added to $1 / 5 \mathrm{~mL}$ Folin-Ciocalteu reagent (10\%) and $1 \mathrm{~mL} \mathrm{Na}{ }_{2} \mathrm{CO}_{3}(7.5 \%)$. The liquid mixture was let to standing for 30 minutes and phenolic content was measured at $760 \mathrm{~nm}$.

\section{Determination of Total Flavonoid Content:}

Flavonoid contents in the root extracts were determined by aluminium chloride. $0.1 \mathrm{~mL}$ methanolic extract of the root was mixed with $0.2 \mathrm{~mL}$ of $80 \%$ methanol, $0.2 \mathrm{~mL}$ of aluminum chloride (10\%), $0.2 \mathrm{~mL}$ of sodium acetate. samples were allowed to standing for $30 \mathrm{~min}$, Absorbance of the reaction mixtures was recorded at $415 \mathrm{~nm}$. Results were represented as mg. $\mathrm{g}^{-1} \mathrm{FW}$ (Chang et al. 2002). 


\section{Measurement of PAL and TAL enzymes activity:}

$300 \mathrm{mg}$ of root samples were grinded at $4^{\circ} \mathrm{C}$ with $4 \mathrm{~mL}$ buffer $(50 \mathrm{mmol} / \mathrm{L}$ Tris $\mathrm{pH} 8.5,14.4 \mathrm{mmol} / \mathrm{L}$ 2-mercaptoethanol, $5 \%$ $\mathrm{w} / \mathrm{v}$ polyvinyl polypyrrorolidone) and the homogenate was centrifuged at $6,000 \mathrm{~g}$ for $10 \mathrm{~min}$ at $4^{\circ} \mathrm{C}$. The total protein content was measured by Bradford (1976) method. The reaction mixture contained $500 \mu \mathrm{mol}$ Tris- $\mathrm{HCl}$ buffer (pH 8$), 100 \mu \mathrm{L}$ of enzyme extracts and either or $5.5 \mu \mathrm{mol}$ of L-tyrosine (Sigma, USA) for measuring TAL activity (EC 4.3.1) or $6 \mu \mathrm{mol}$ of Lphenylalanine for measuring PAL activity (EC 4.3.1.5). The contents of trans-cinnamic and p-coumaric acids were determined by measuring absorbance at 290 and $333 \mathrm{~nm}$, respectively (Beaudoin-Eagan and Thorpe 1985).

\section{Membrane permeability (electrolyte leakage) assay:}

$0.2 \mathrm{~g}$ fresh roots were incubated with $25 \mathrm{~mL}$ double-distilled water for $24 \mathrm{~h}$ at room temperature on shaker. Digital conductometer was used for measuring The initial electrical conductivity (EC1). Bottles containing some roots were also autoclaved for $15 \mathrm{~min}$ at $120^{\circ} \mathrm{C}$, then conductivity (EC2) was measured again (Lutts et al. 1995). Relative electrolyte leakage (REL) was estimated as:

$\mathrm{REL}=(\mathrm{EC} 1 / \mathrm{EC} 2) \times 100$

\section{Malondialdehyde (MDA) assay:}

Thiobarbituric acid-reactive substance (TBARS) was measured as MDA. Root sample $(0.2 \mathrm{~g})$ was homogenized in $2 \mathrm{~mL}$ of $0.1 \%(\mathrm{w} / \mathrm{v}$ ) trichloroacetic acid (TCA) that follow by centrifuged at $10000 \mathrm{rpm}$ for $20 \mathrm{~min}$. Then, $4 \mathrm{~mL}$ of $20 \%$ TCA containing $0.5 \%(\mathrm{w} / \mathrm{v})$ TBA was added to $1 \mathrm{~mL}$ of supernatant. The mixture was warmed at $95 \circ \mathrm{C}$ for $25 \mathrm{~min}$ and immediately cooled to stop the reaction. The concentration of MDA was calculated by an extinction co-efficient of $155 \mathrm{mM}^{\mathrm{cm}}{ }^{-1}$. (Heath and Packer 1968)

\section{Proline concentration:}

Free proline amount in alfalfa roots was measured by ninhydrin assay at $520 \mathrm{~nm}$ by colorimetric determinations, according to the method of Bates et al. (1973). The proline content was represented as $\mu \mathrm{mol} . \mathrm{g}^{-1} \mathrm{FW}$.

\section{$\mathrm{Na}^{+}$and $\mathrm{K}^{+}$content:}

Dry root was grinded into a fine powder, and finally digested in a solution of sulfosalicylic acid $3 \%$ for $24 \mathrm{~h}$ in the refrigerator. Subsequently, the $\mathrm{K}^{+}$and $\mathrm{Na}^{+}$ions were measured by flame photometer (Halstead Essex-corning-England) using standard solutions (Shi et al. 2012).

\section{Measurement of Glycine betaine (GB).}

Glycine betaine was extracted from the oven dried and grinded roots using Grieve and Grattan method (1983).

\section{Staining and quantification of $\mathrm{H}_{2} \mathrm{O}_{2}$ :}

$50 \mathrm{mg}$ fresh roots were ground with $2 \mathrm{~mL}$ of $0.1 \%$ trichloroaceticacid (TCA) and The homogenates were centrifuged and after that, added to $0.5 \mathrm{~mL}$ of $10 \mathrm{mM}$ potassium phosphate buffer $(\mathrm{pH} 7.0)$ with $1 \mathrm{~mL}$ of $1 \mathrm{M} \mathrm{KI}$ (potassium iodide). Absorbance was recorded at $390 \mathrm{~nm}$ using a multi-mode reader. The $\mathrm{H}_{2} \mathrm{O}_{2}$ content was calculated by extinction coefficient $\left(0.28 \mu \mathrm{M}^{-1}\right.$ $\left.\mathrm{cm}^{-1}\right)$ and results were expressed as $\mu \mathrm{mol} . \mathrm{g}^{-1} \mathrm{FW}$ (Velikova et al. 2000). Accumulations of the hydrogen peroxide $\left(\mathrm{H}_{2} \mathrm{O}_{2}\right)$ were observed by histochemical staining methods (Thordal-Christensen et al. 1997). $\mathrm{H}_{2} \mathrm{O}_{2}$ was stained using 3,3'diaminobenzidine (DAB) staining. Excised roots were immersed in a solution of $0.1 \% \mathrm{DAB}(\mathrm{PH}=3.8)$ for $12 \mathrm{~h}$ in darkness. The brown color on the roots indicated presence of hydrogen peroxide.

\section{Staining and quantification of $0^{2-}$ :}


Presence of the superoxide ion $\mathrm{O}^{-2}$ was measured by Nitroblue tetrazolium (NBT) staining. Roots were incubated in $50 \mathrm{mM}$ phosphate buffer ( $\mathrm{pH}$ 6.4) containing $0.1 \%$ NBT and $10 \mathrm{mM}$ sodium azid. Samples were shaken in darkness for $12 \mathrm{~h}$ (80 $\mathrm{rpm} / \mathrm{min}$ ). Blue formazan compounds were visualized at the position of NBT precipitation (Fryer et al. 2002). $0^{2-}$ content was measured according to the method of Rook et al. (1985) with a slight modification.

\section{ROS measurement:}

Cellular ROS levels measured based on Mahalingam et al. (2006) which 2', 7' -dichlorofluorescin diacetate (DCFDA) is oxidized and converted to fluorescence dye 2', 7' - dichlorofluorescein (DCF). About $100 \mathrm{mg}$ fresh root was ground with 10 $\mathrm{mM}$ Tris- $\mathrm{HCl}\left(\mathrm{pH}:\right.$ 7.2). The homogenates were centrifuged at $14000 \mathrm{~g}$ for $20 \mathrm{~min}$ at $4^{\circ} \mathrm{C}$. Then $950 \mu \mathrm{l}$ supernatant was added to $50 \mu \mathrm{l}$ of $1 \mathrm{mM}$ DCFDA. The fluorescence of the samples was determined on excitation/emission wavelength: $480 / 520 \mathrm{~nm}$.

\section{Endogenous melatonin and auxin content:}

Endogenous melatonin and auxin content in alfalfa root and leaf were estimated using HPLC method (Iriti et al. 2006). Root and leaf $(1 \mathrm{~g})$ were grinded with liquid nitrogen. The powder was then dispersed in $5 \mathrm{~mL}$ of pure methanol, followed by centrifugation at $10000 \mathrm{~g}$ for $10 \mathrm{~min}$ at $4{ }^{\circ} \mathrm{C}$. The supernatants then, were filtered by sterile Millipore filter $0.22 \mu$. Unit is Shimadzu Nexera X2 such as Pump LC-30AD, Auto sampler SIL-30AC (Injection volume: 40ul) Column oven CTO-20A (42 ${ }^{\circ} \mathrm{C}$ ), Detector UV/VIS SPD-20A, Isocratic mode, Flow rate: 0.7ml/min, Run time: 8min, Column C18: Macherey-Nagel (150/4.6 Nucleodur C18 gravity, 5um). Method was used, Methanol 40, Acetonitrile 40, Water 20(v/v). Melatonin was detected at 310 $\mathrm{nm}$ and auxin content at $259 \mathrm{~nm}$. Standard curve was obtained by melatonin and auxin standard.

\section{Statistical analysis:}

All experiments were analyzed by two-way ANOVA and Duncan's multiple range test $(P<0.05)$. Each sample value was at least in three replicates and was reported as mean \pm standard deviation (SD). PCA was applied for determining the best target between several physiological factors for melatonin under salinity.

\section{Result:}

\section{Effects of melatonin treatment on root growth of alfalfa under salinity stress:}

Increasing $\mathrm{NaCl}$ concentration negatively affected the fresh weight, dry weight, root length and lateral root number in alfalfa roots (Table 1). The results indicated that the dry weight and fresh weight were significantly increased by melatonin treatments with $150 \mathrm{mM}$ salt treatment. Salt stress (150 and $200 \mathrm{mM} \mathrm{NaCl}$ ) noticeably inhibited the root growth of alfalfa seedlings. Application of $0.1 \mu \mathrm{M}$ melatonin could also effectively alleviated root growth parameters, specifically under salt stress. This feature was proved by increasing of the root length (Table 1). The lateral root number was decreased by increasing salinity, but 0.1 and $10 \mu \mathrm{M}$ melatonin improved that compare to the control. The results indicated that applied melatonin increase salt tolerance of alfalfa roots.

\section{Effect of melatonin on Phenolic compounds, Phenylalanine ammonia-lyase (PAL) and tyrosine ammonia-lyase (TAL) activities in alfalfa root:}

Salt stress noticeably caused decrease content of Total Phenol, Anthocyanin and Flavonoids in alfalfa root compared with untreated root. On the other hand, melatonin pretreatment had no effect on Anthocyanin content either with or without salt treatment. According to our results, melatonin as a single treatment is able to increasing Total Phenol and Flavonoids.

Moreover, melatonin improved phenol and Flavonoids contents in the medium supplemented with salt. As the results show in Table 2, PAL and TAL activities decreased notably as the rate of salinity increased. In the presence of melatonin without salt treatment, PAL and TAL activity significantly raised compared with control. Salt stress induced by $\mathrm{NaCl}$ in combination with 
melatonin treatments dramatically increased PAL and TAL activities with 10 and $15 \mu \mathrm{M}$ Melatonin having a more pronounced effect on PAL and TAL activity under salt stress (Table 2).

\section{Effect of Melatonin on soluble carbohydrate, proline and Glycine Betaine content:}

Soluble sugar, Proline and Glycine Betaine usually act as important osmotic regulators in root. Results show that application of 150 and $200 \mathrm{mM} \mathrm{NaCl}$ declined the content of soluble carbohydrate by $44 \%$ and $55 \%$ respectively compared with control root. Melatonin treatment significantly increased soluble sugar in the root under salt stress specifically in $200 \mathrm{mM} \mathrm{NaCl}$. It seems that, $10 \mu \mathrm{M}$ melatonin had the positive effect on this osmolyte (Fig. 1A). Figure 1B shows proline contents in alfalfa root under salt stress treatment with melatonin. Salinity caused significant increase in proline. Our results presented that the amount of proline increased from 100.18 in control sample to 396.89 and $530.67 \mu \mathrm{mol} . \mathrm{g}^{-1} \mathrm{FW}$ in 150 and $200 \mathrm{mM} \mathrm{NaCl}$. Application of $0.1 \mu \mathrm{M}$ melatonin dramatically raised proline content in $200 \mathrm{mM}$ salt treated roots (Fig. 1B). Glycine betaine accumulation in salt stress is considered as a sign of salinity tolerance. The results in figure $1 \mathrm{C}$ show that, the two applied salinity levels (150 and $200 \mathrm{mM} \mathrm{NaCl}$ ) caused gradual increases in glycine betaine relative to control root. Melatonin concentrations $(0.1,10$ and $15 \mu \mathrm{M})$ elevated glycine betaine content relative to their corresponding controls.

\section{Effects of Melatonin on relative Electrolyte leakage, Malondialdehyde (MDA), ROS (Reactive Oxygen Species), $\mathrm{H}_{2} \mathrm{O}_{2}$ and $\mathrm{O}^{2-}$ under salinity stress:}

Our results indicated that, under salt stress MDA and EL increased by high salinity. Application of melatonin showed no obvious changes in EL and MDA in control sample and $10 \mu \mathrm{M}$ melatonin had the minimum effect on MDA and EL under $200 \mathrm{mM}$ salt (Table 3). When salt treatment was performed, melatonin-treated plants showed notably lower contents of MDA, and $\mathrm{EL}$ compared with control. $\mathrm{H}_{2} \mathrm{O}_{2}$ and $\mathrm{O}^{2-}$ level are indexes of the status of ROS-scavenging ability in root under oxidative stress. As shown in Table 3, ROS, $\mathrm{O}^{2-}$ and $\mathrm{H}_{2} \mathrm{O}_{2}$ content were increased by $\mathrm{NaCl}$ stress. There were no obvious significant differences between the control and melatonin-treated without salt stress. However, melatonin pretreatment significantly decreased $\mathrm{NaCl}$-induced accumulation of ROS, $\mathrm{O}^{2-}$ and $\mathrm{H}_{2} \mathrm{O}_{2}$. The optimum concentration of melatonin for $\mathrm{NaCl}$ alleviating was $0.1 \mu \mathrm{M}$. This concentration of melatonin decreased the $\mathrm{O}^{2-}, \mathrm{H}_{2} \mathrm{O}_{2}$ and ROS content of the roots (Table 3 ).

\section{Detection of $\mathrm{H}_{2} \mathrm{O}_{2}$ and $\mathrm{O}^{2}$ in alfalfa root:}

Under histochemical staining, $\mathrm{H}_{2} \mathrm{O}_{2}$ indicated by brown spots and $\mathrm{O}^{2-}$ distinguished by dark blue spots (Fig 2. A-B). Significant accumulation of $\mathrm{H}_{2} \mathrm{O}_{2}$ and $\mathrm{O}^{2-}$ showed in $\mathrm{NaCl}$ - treated roots, and high concentration of salinity increased the number of stained spots. Interestingly, melatonin treatment reduced the number of stained spots induced by $\mathrm{H}_{2} \mathrm{O}_{2}$ and $\mathrm{O}^{2-}$. Our results indicated that, among different amount of melatonin, $0.1 \mu \mathrm{M}$ melatonin had a significant influence on decreasing of $\mathrm{O}^{2}$ level under salinity stress. Similarly, accumulation of $\mathrm{H}_{2} \mathrm{O}_{2}$ in alfalfa root treated with only salinity revealed several brown spots while, melatonin suppressed accumulations of $\mathrm{H}_{2} \mathrm{O}_{2}$ in alfalfa roots.

\section{Effects of Melatonin on $\mathrm{K}^{+}$and $\mathrm{Na}^{+}$content:}

As the result show (Fig. 3A, B, C), the $\mathrm{Na}^{+}$content in root with salt stress treatment was significantly higher than that in nonstressed root, and melatonin pretreatment reduced $\mathrm{Na}^{+}$accumulation under saline conditions. Salt stress treatment reduced $\mathrm{K}^{+}$uptake, and melatonin pretreatment increased $\mathrm{K}^{+}$uptake under salt stress conditions specifically in $200 \mathrm{mM}$ salt. $0.1 \mu \mathrm{M}$ melatonin dramatically enhanced the concentrations of $\mathrm{K}^{+}$and decreased $\mathrm{Na}^{+}$content under salinity stress in alfalfa root.

\section{Quantitation of endogenous melatonin and auxin content in Alfalfa seedlings:}

To examine the role of melatonin in plants' response to salt stress, the endogenous melatonin production in alfalfa leaf and root was measured exposure to salt stress. Endogenous melatonin content was approximately $20 \mathrm{ng} . \mathrm{g}^{-1} \mathrm{FW}$ at control leaf. 
As the results show (Fig. 4A) $15 \mu \mathrm{M}$ melatonin had the highest melatonin index (without salinity). Salt stress substantially decreased melatonin content in alfalfa leafs. However, pretreatment with exogenous melatonin significantly increased

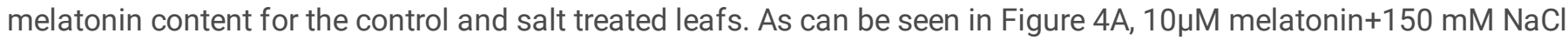
increased melatonin content by 4 folds as compared to the control. Figure 4B shows that exogenous application of melatonin had a considerable effect on auxin levels in alfalfa leaf. Pretreatment with $10 \mu \mathrm{M}$ melatonin under $150 \mathrm{mM} \mathrm{NaCl}$ induced salinity increased auxin content and significantly improved the accumulation of endogenous melatonin in alfalfa leafs. As the result shown in figure 4C, melatonin concentration increased in non-salt treated root compared to the control. Supplemented of the medium with $10 \mu \mathrm{M}$ melatonin showed the highest melatonin content under salt stress. In Figure 4D, high salt concentrations increased root auxin content but exogenous melatonin enhanced the auxin content. The application of $15 \mu \mathrm{M}$ melatonin dramatically raised amount of auxin in treated roots with $200 \mathrm{mM}$ salt. As shown in figures $4 \mathrm{E}$ and $4 \mathrm{~F}$, salinity caused significant increase in IAA / melatonin ratio but, melatonin treatment reduced IAA / melatonin ratio under salt stress in alfalfa shoot but this ration was increased in alfalfa roots, in $200 \mathrm{mM}$ salinity.

\section{Identification of Melatonin and $\mathrm{NaCl}$ targets:}

principal component analysis (PCA) was performed to identifying the major objectives for melatonin and salinity in the alfalfa root. PCA1 and PCA2 were reported from the root growth parameters as well as physiological and biochemical factors (Fig. 5A). In fact, PCA presented the best objectives of melatonin and $\mathrm{NaCl}$ on alfalfa root under tissue culture condition (Fig. 5B). The PCA results determined root growth parameters, which might separate into two separate groups. Figure 5B, summarizes a simple model of the major objectives for melatonin and salt. We found that glycine betaine, auxin content, soluble carbohydrate and flavonoid were the main melatonin objectives in alfalfa. In conclusion, the main targets of $\mathrm{NaCl}$ were $\mathrm{H}_{2} \mathrm{O}_{2}, \mathrm{O}^{2-}$, ROS, MDA, PAL and $\mathrm{K}^{+} / \mathrm{Na}^{+}$in PCA analysis.

\section{Discussion}

Salinity is one of the most serious abiotic stresses that limit root growth. Higher plants have developed several strategies in reply to various stresses. Melatonin is thought to improving plant tolerance to environmental stresses responses (Arnao and Hernández-Ruiz 2014). Plants can also absorb and accumulate exogenous melatonin in their tissue (Tan et al. 2012). Responses to melatonin in regulating root growth and development are dose dependent even in the same species under stress conditions. In the present study, salinity significantly decreased root physiological and growth parameters; however, the positive protective role of melatonin improved root growth of alfalfa seedlings. We showed that $0.1 \mu \mathrm{M}$ melatonin increased the dry and fresh weight of alfalfa root treatment with salt. Since melatonin as an indoleamine shares structural similarity with Indole-3-acetic-acid (IAA), and endogenous IAA also is increased by exogenous melatonin it may play a role similar to auxins consequently, due to enhancement of the root growth, the fresh and dry weight of alfalfa root was increased. Furthermore, melatonin- triggered IAA synthesis also increased IAA / melatonin ratio in alfalfa root indicating the similar impact of IAA and melatonin under salt stress (Chen et al. 2009). It seemed that, the balance among endogenous hormones might be responsible for root growth regulation under stress condition (Arnao and Hernández-Ruiz 2018).

Previous studies reported, melatonin augmented other antioxidant agents such as phenolic compounds, flavonoids and anthocyanins. Similar effect on phenolic compounds was observed in alfalfa root, when plants exposed to salt stress conditions supplemented with 10 and $15 \mu \mathrm{M}$ melatonin compared with only salt treatment. Phenolic compounds with antioxidant property could affect alfalfa root either by capturing unpaired electrons or by prohibiting the function of the radical oxygen species. In agreement with our data, Olenichenko reported that, (Olenichenko and Zagoskina 2005) cold stress increased phenolic content in wheat, and salt stress in Vigna radiate (Dawood and El-Awadi 2015). Interestingly, PCA results showed, flavonoid was strongly correlated with melatonin whereas anthocyanin was not affected under salt stress. Since salinity increased PAL and TAL enzymes' activities in alfalfa root, and based on Zhang, (Zhang et al. 2016) findings in other plant species, it can be implied that these two key enzymes were target of salinity in the present study. 
Lipid peroxidation assessment by MDA content is a widely used sign of membrane damage due to increasing in free radicals, which causes peroxidation of polyunsaturated fatty acids, and enhancement of the content of MDA. Oxidative damage affects on the membrane's integrity under salt stress and the best indicator for this case is electrolyte leakage (Wang et al. 2016). Salt stress affected the MDA content as an objective of salinity in alfalfa root and melatonin with antioxidant ability could reduce lipid peroxidation, neutralizing the effect of salinity on membrane permeability. Melatonin could attenuate oxidative damage caused by salt stress in alfalfa root with decreasing amount of superoxide anion and $\mathrm{H}_{2} \mathrm{O}_{2}$. This can be partially due to the fact that melatonin with broad-spectrum antioxidant could remove $\mathrm{H}_{2} \mathrm{O}_{2}$ produced by salt stress (Arnao and Hernández-Ruiz 2015). In the cell membranes, melatonin can be located in the polar heads of lipids and so, can alleviate the lipid peroxidation and preserve membrane permeability. The positive effects of melatonin on the MDA and membrane damage under salt and water-stress have been expressed (Zhang et al. 2013) supporting our observations that antioxidant ability of melatonin reduced MDA content and percentage of electrolyte leakage.

In alfalfa root, $0.1 \mu \mathrm{M}$ melatonin was more effective than other concentrations in terms of $\mathrm{ROS}, \mathrm{H}_{2} \mathrm{O}_{2}$ and $\mathrm{O}^{2-}$ reduction under high level of salinity. ROS content reduced by melatonin pretreatment can be related to induction of antioxidant factors. Melatonin by reducing radical generation in mitochondria and neutralizes free radicals, recognized as a mitochondrial antioxidant (Tan et al, 2002). For removing free radicals, melatonin speeds up the electron flow through the ETC (Electron Transport Chain) and slightly activates the MPTP (Mitochondrial Permeability Transition Pore). protection of mitochondria against oxidative damages is one of the important role of melatonin. (Tan et al, 2012). Our results and staining of $\mathrm{H}_{2} \mathrm{O}_{2}$ and $\mathrm{O}^{2-}$ are consistent with those reported by other authors (Shi et al. 2015; Wei et al. 2015). Our data suggested that, application of exogenous melatonin as a crucial antioxidant alleviated ROS accumulation in alfalfa root.

Glycine betaine (GB), proline and carbohydrate contents are the major organic osmolytes which are accumulated in plants in response to different stresses. These have an osmoprotectant function preventing dehydration of cytoplasm, protecting water around proteins and maintaining turgor pressure in cells (Smirnoff 1993). Glycine betaine has an important role in the adjustment of cells to various adverse environmental stresses through increasing osmotic pressure in the cytoplasm, stabilizing membranes and proteins, and preserving the relatively water content required for root development and cellular function. This investigation showed that, salt stress improved proline and GB content in root, whereas exogenous melatonin led to more increase in GB content but did not significantly affect proline content. Our work on alfalfa is supported by Sarropoulou et al. (2012) who reported, in the roots of cherry rootstock PHL-C (Prunus avium $\times$ Prunus cerasus), melatonin enhanced the carbohydrate contents by 1.5 times, while significantly reduced the proline content.

When alfalfa roots were cultured in the medium containing $\mathrm{NaCl}$, salinity reduced carbohydrates content in root compared to control, whereas exogenous melatonin led to significant increase in carbohydrate levels under salt stress. The present study indicates that, perhaps melatonin increases the carbohydrate synthesis by expression of trehalose synthesis gene as described by Jain and Roy. Furthermore, carbohydrates may act as free radical scavengers and contribute to enhancement in membrane stabilization (Shi et al. 2015; Jain and Roy 2009).

Since PCA indicated that soluble carbohydrate was an important target for melatonin in alfalfa root, we can conclude that compatible solutes might be a part of an adaptive process contributing to osmotic adjustment under severe salinity. However, further studies may be needed to clarify the relationship among melatonin, proline, Glycine betaine and carbohydrates.

It has been shown that melatonin significantly decreases accumulation of $\mathrm{Na}^{+}$and markedly increases $\mathrm{K}^{+}$contents under salinity stress. Our data showed an increase of $\mathrm{Na}^{+}$contents and a significant decrease of $\mathrm{K}^{+}$contents in the root when root were exposed only to salinity stress and no melatonin. While, melatonin enabled root to maintain significantly higher $\mathrm{K}^{+}$ content compared to control. Under salt stress in alfalfa root maintaining ion homeostasis using melatonin might be possible by regulating the gene expression and activity of $\mathrm{K}^{+}$and $\mathrm{Na}^{+}$transporters as reported in Arabidopsis thaliana (Shi et al. 2003). 
Plant hormones are critical component for improving growth of roots and shoots. Melatonin widely takes part in the metabolism of some plant hormones, such as indole-3-acetic acid (IAA), abscisic acid (ABA), gibberellic acids (GA), cytokinins (CK), and ethylene (Arnao and Hernández-Ruiz 2018). Our study presented, exogenous melatonin caused changes in the concentration of endogenous free IAA in alfalfa root and leaf. Salt stress supplemented with melatonin, the amount of melatonin and IAA in alfalfa leaf and root were higher in treated plants compared with control plants. However, melatonin content in leaf and root decreased in high salt treatment when no melatonin was applied. It seems that melatonin promoted growth and development of alfalfa roots through an IAA-dependent pathway. In contrast, in overproducing melatonin plants, a significant decrease in IAA levels has occurred possibly by inhibiting expression of PIN1, 3, 7 and decreasing IAA levels as reported in Arabidopsis roots (Wang et al. 2016). Therefore, it can be postulated that, it may manage auxin synthesis and polar auxin transport in plants. We present a new perspective on the relationship between auxin, melatonin and alfalfa root growth against salinity stress. Exogenous application of melatonin improved growth of alfalfa roots in tissue culture by inducing of some antioxidant defense systems.

\section{Concluding Remarks:}

Roots use several methods to deal with salt stress; such as elimination of ions, production of compatible solutes, stimulation of antioxidant enzymes, and induction of phytohormones. The present results showed that melatonin might behave as excellent free radical scavengers by changes of IAA content, GB, flavonoids and soluble carbohydrates. On the other hand, ROS, $\mathrm{H}_{2} \mathrm{O}_{2}, \mathrm{O}^{2-}$, MDA and PAL seemed to be targets of salinity stress based on PCA. Application of exogenous melatonin increased phenol, endogenous melatonin and $\mathrm{K}^{+}$content. Furthermore, melatonin with antioxidant capacity decreased electrolyte leakage and reduced $\mathrm{Na}^{+}$accumulation in alfalfa root.

\section{Declarations}

\section{Acknowledgement:}

Author would like to thank Plant Antioxidant Center of Excellence (OACE), University of Isfahan for their support. We also acknowledge Prof. Acram Taji for extensive English editing of the manuscript.

\section{References}

Arnao M, Hernández-Ruiz j (2014) Melatonin: plant growth regulator and/or biostimulator during stress? Trends Plant Sci 19:789-797.

Arnao MB, Hernández-Ruiz J (2015) Functions of melatonin in plants. J Pineal Res 59(2):133-50.

Arnao MB, Hernández-Ruiz J (2018) Melatonin and its relationship to plant hormones. Ann Bot. 121(2):195-207.

Bates LS, Waldren RP, Teare ID (1973) Rapid determination of free proline for water-stress studies. Plant Soil 39:205-207.

Beaudoin-Eagan LD, Thorpe TA (1985) Tyrosine and phenylalanine ammonia lyase activities during shoot initiation in tobacco callus cultures. Plant Physiol 78:438-441.

Bhattarai S, Biswas D, Fu YB, Biligetu B (2020) Morphological, Physiological, and Genetic Responses to Salt Stress in Alfalfa. Agronomy 10(4), 577.

Bradford MM (1976) A rapid and sensitive method for the quantitation of microgram quantities of protein utilizing the principle of protein-dye binding. Anal Biochem 72:248-254. 
Chang CC, Yang MH, Wen HM, Chern JC (2002) Estimation of total flavonoid content in propolis by two complementary colorimetric methods. J Food Drug Anal 10:178-182.

Chen Q, Qi WB, Reiter RJ, Wei W, Wang BM (2009) Exogenously applied melatonin stimulates root growth and raises endogenous IAA in roots of etiolated seedling of Brassica juncea. J Plant Physiol 166:324-328.

Dawood MG, El-Awadi ME (2015) Alleviation of salinity stress on Vicia faba L. plants via seed priming with melatonin. Acta biol Colomb 20(2):223-235.

Dubois M, Gilles KA, Hamilton JK, Rebers P, Smith F (1956) Colorimetric method for determination of sugars and related substances. Anal Chem 28:350-356

Fryer MJ, Oxborough K, Mullineaux PM, Baker NR (2002) Imaging of photo-oxidative stress responses in leaves. J Exp Bot 53: $1249-1254$

Grieve C, Grattan S (1983) Rapid assay for determination of water soluble quaternary ammonium compounds. Plant Soil 70:303-307.

Heath RL, Packer L (1968) Photoperoxidation in isolated chloroplasts: I. Kinetics and stoichiometry of fatty acid peroxidation. Arch Biochem Biophys 125:189-198.

Iriti M, Rossoni M, Faoro F (2006) Melatonin content in grape: myth or panacea?. J Sci Food Agric 86:1432-1438.

Jain NK, Roy I (2009) Effect of trehalose on protein structure. Protein Sci 18(1):24-36.

Kim M, Seo H, Park C, Park WJ (2016) Examination of the auxin hypothesis of phytomelatonin action in classical auxin assay systems in maize. J Plant Physiol 190:67-71.

Korkmaz A, Karakas A, Kocacinar F, Cuci Y (2017) The effects of seed treatment with melatonin on germination and emergence performance of pepper seeds under chilling stress. J Agric Sci 23:167-176.

Kumar S (2011) Biotechnological advancements in alfalfa improvement. Journal of Applied Genetics 52: 111-124.

Lutts S, Kinet J, Bouharmont J (1995) Changes in plant response to $\mathrm{NaCl}$ during development of rice (Oryza sativa L.) varieties differing in salinity resistance. J Exp Bot 46:1843-1852.

Mahalingam R, Jambunathan N, Gunjan SK, Faustin E, Weng H, Ayoubi P (2006) Analysis of oxidative signaling induced by ozone in Arabidopsis thaliana. Plant Cell Environ 29(7):1357-71. doi: 10.1111/j.1365-3040.2006.01516.x. PMID: 17080957.

Mukherjee S, David A, Yadav S, Baluska F, Bhatla SC (2014) Salt stress-induced seedling growth inhibition coincides with differential distribution of serotonin and melatonin in sunflower seedling roots and cotyledons. Physiol Plant 152:14-728.

Munns R, Tester M (2008) Mechanisms of salinity tolerance. Annu Rev Plant Biol 59:651-681.

Murashige T, Skoog F (1962) A revised medium for rapid growth and bio assays with tobacco tissue cultures. Physiol Plant $15: 473-497$

Murch SJ, KrishnaRaj S, Saxena PK (2000) Tryptophan is a precursor for melatonin and serotonin biosynthesis in in vitro regenerated Hypericum perforatum plants. Plant Cell Rep 19:698-704.

Olenichenko NA, Zagoskina NV (2005) Response of winter wheat to cold: production of phenolic compounds and Lphenylalanine ammonia lyase activity. App Biochem Microbio 41:600-603

Parida AK, Das AB (2005) Salt tolerance and salinity effects on plants. Ecotoxicol Environ Safa 60:324-349. 
Pourcel L, Routaboul JM, Cheynier V, Lepiniec L, Debeaujon I (2007) Flavonoid oxidation in plants: from biochemical properties to physiological functions. Trends Plant sci 12: 29-36.

Rook GA, Steele J, Umar S, Dockrell HM (1985) A simple method for the solubilisation of reduced NBT, and its use as a colorimetric assay for activation of human macrophages by gamma-interferon. J Immunol Methods 82, 161- 167.

Sarropoulou V, Dimassi-Theriou K, Therios I, Koukourikou-Petridou M (2012) Melatonin enhances root regeneration, photosynthetic pigments, biomass, total carbohydrates and proline content in the cherry rootstock PHL-C (Prunus avium $\times$ Prunus cerasus). Plant Physiol Biochem 61:162-8.

Shi H, Jiang C, Ye T, Tan DX, Reiter RJ, Zhang H, Liu R, Chan Z (2015) Comparative physiological, metabolomic, and transcriptomic analyses reveal mechanisms of improved abiotic stress resistance in bermudagrass [Cynodon dactylon ( $\mathrm{L}$ ). Pers.] by exogenous melatonin. J Exp Bot 66(3):681-94. doi: 10.1093/jxb/eru373. Epub 2014 Sep 15. PMID: 25225478; PMCID: PMC4321537.

Shi G, Liu C, Cui M, Ma Y, Ca Q (2012) Cadmium tolerance and bioaccumulation of 18 hemp accessions. Appl Biochem Biotechnol 168(1):163-73.

Singleton VL, Orthofer R, Lamuela-Raventos RM (1999) Analysis of total phenols and other oxidation substrates and antioxidants by means of folinciocalteu reagent. Methods Enzymol 299:152-178.

Smirnoff N (1993) The role of active oxygen in the response of plants to water deficit and desiccation. New Phytol 125:27-58.

Tan DX, Hardeland R, Manchester LC, Korkmaz A, Ma S, Rosales-Corral S, Reiter RJ (2012) Functional roles of melatonin in plants, and perspectives in nutritional and agricultural science. J Exp Bot 63:577-597.

Tan DX, Reiter RJ, Manchester LC, Yan M, El-Sawi M, Sainz RM, Mayo JC, Kohen R, Allegra M, Hardeland R (2002) Chemical and physical properties and potential mechanisms: melatonin as a broad spectrum antioxidant and free radical scavenger. Curr Top Med Chem 2:181-97; PMID:11899100; http://dx.doi.org/ 10.2174/1568026023394443

Thordal-Christensen $\mathrm{H}$, Zhang Z, Wei Y, Collinge DB (1997) Subcellular localization of $\mathrm{H}_{2} \mathrm{O}_{2}$ in plants. $\mathrm{H}_{2} \mathrm{O}_{2}$ accumulation in papillae and hypersensitive response during the barley-powdery mildew interaction. Plant J 11(6):1187-94.

Velikova V, Yordanov I, Edreva A (2000) Oxidative stress and some antioxidant systems in acid rain-treated bean plants: protective role of exogenous polyamines. Plant Sci 151(1):59-66.

Wagner GJ (1979) Content and vacuole/extravacuole distribution of neutral sugars, free amino acids, and anthocyanin in protoplasts. Plant Physiol 64(1):88-93.

Wang Q, An B, Wei Y, Reiter RJ, Shi H, Luo H, He C (2016) Melatonin Regulates Root Meristem by Repressing Auxin Synthesis and Polar Auxin Transport in Arabidopsis. doi.org/10.3389/fpls.2016.01882

Wang LY, Liu JL, Wang WX, Sun Y (2015) Exogenous melatonin improves growth and photosynthetic capacity of cucumber under salinity-induced stress. Photosynthetica 54(1):19-27.

Weeda S, Zhang N, Zhao X, Ndip G, Guo Y, Buck GA, Fu C, Ren SX (2014) Arabidopsis transcriptome analysis reveals key roles of melatonin in plant defense systems. PLOS ONE 9:e93462.doi:10.1371/journal.pone.0093462

Wei W, Li QT, Chu YN, Reiter RJ, Yu XM, Zhu DH, Zhang WK, Ma B, Lin Q, Zhang JS (2015) Melatonin enhances plant growth and abiotic stress tolerance in soybean plants. J Exp Bot 66: 695-707

Zhang N, Sun Q, Li H, Li X, Cao Y, Zhang H, Li S, Zhang L, Qi Y, Ren S, Zhao B, Guo YD (2016) Melatonin Improved Anthocyanin Accumulation by Regulating Gene Expressions and Resulted in High Reactive Oxygen Species Scavenging 
Capacity in Cabbage. Front Plant Sci 7:197.

Zhang N, Zhao B, Zhang HJ (2013) Melatonin promotes water stress tolerance, lateral root formation, and seed germination in cucumber (Cucumis sativus L.). J Pineal Res 54:15-23.

Zuo B, Zheng X, He P, Wang L, Lei Q, Feng C, Zhou J, Li Q, Han Z, Kong J (2014) Overexpression of MzASMT improves melatonin production and enhances drought tolerance in transgenic Arabidopsis thaliana plants. J Pineal Res 57(4):408-17.

\section{Tables}

Table 1: Effects of Melatonin and $\mathrm{NaCl}$ on Root fresh weight, Root Dry weight, Mean of root length and Lateral Root Number of alfalfa root. Values express the means $\pm S D,(n=3)$ and according to Duncan's multiple range tests, letters indicate significant differences at $\mathrm{P}<0.05$.

\begin{tabular}{|c|c|c|c|c|c|}
\hline Salt & Treatment & $\begin{array}{l}\text { Root fresh Weight } \\
\text { (g) }\end{array}$ & $\begin{array}{l}\text { Root Dry Weight } \\
\text { (g) }\end{array}$ & $\begin{array}{l}\text { Mean of Root Length } \\
(\mathrm{cm})\end{array}$ & $\begin{array}{l}\text { Lateral Root } \\
\text { Number }\end{array}$ \\
\hline \multirow[t]{4}{*}{$0 \mathrm{mM} \mathrm{NaCl}$} & control & $0.13^{a} \pm 0.002$ & $0.01^{a} \pm 6 * 10^{-4}$ & $5.75^{a b} \pm 0.05$ & $11^{\mathrm{a}} \pm 1.2$ \\
\hline & $\begin{array}{l}0.1 \mu \mathrm{M} \\
\mathrm{MT}\end{array}$ & $0.14^{a} \pm 0.02$ & $0.01^{\mathrm{a}} \pm 0.001$ & $7.06^{\mathrm{a}} \pm 0.2$ & $9^{a b} \pm 1.3$ \\
\hline & $\begin{array}{l}10 \mu \mathrm{M} \\
\mathrm{MT}\end{array}$ & $0.13^{\mathrm{a}} \pm 0.04$ & $0.01^{\mathrm{a}} \pm 0.002$ & $6.43^{\mathrm{ab}} \pm 0.2$ & $11^{\mathrm{a}} \pm 1.2$ \\
\hline & $\begin{array}{l}15 \mu \mathrm{m} \\
\mathrm{MT}\end{array}$ & $0.14^{\mathrm{a}} \pm 0.03$ & $0.01^{\mathrm{a}} \pm 0.001$ & $4.71^{b} \pm 0.2$ & $8 b^{c} \pm 1.6$ \\
\hline \multirow[t]{4}{*}{$\begin{array}{l}150 \mathrm{mM} \\
\mathrm{NaCl}\end{array}$} & control & $0.03^{\mathrm{cd}} \pm 0.006$ & $0.006^{\mathrm{cd}} \pm 4^{\star} 10^{-4}$ & $3.68^{\mathrm{C}} \pm 0.4$ & $2^{d} \pm 1.2$ \\
\hline & $\begin{array}{l}0.1 \mu \mathrm{M} \\
\mathrm{MT}\end{array}$ & $0.08^{\mathrm{b}} \pm 0.01$ & $0.008^{b} \pm 0.001$ & $6.36^{\mathrm{ab}} \pm 0.2$ & $7^{b c} \pm 1$ \\
\hline & $\begin{array}{l}10 \mu \mathrm{M} \\
\mathrm{MT}\end{array}$ & $0.06^{b c} \pm 0.01$ & $0.009^{b c} \pm 0.002$ & $7.13^{a} \pm 0.2$ & $6^{c} \pm 1.7$ \\
\hline & $\begin{array}{l}15 \mu \mathrm{m} \\
\mathrm{MT}\end{array}$ & $0.06^{\mathrm{bcd}} \pm 0.01$ & $0.006^{\mathrm{cd}} \pm 3^{\star} 10^{-4}$ & $4^{c} \pm 0.4$ & $3^{d} \pm 1.1$ \\
\hline \multirow[t]{4}{*}{$\begin{array}{l}200 \mathrm{mM} \\
\mathrm{NaCl}\end{array}$} & control & $0.02^{d} \pm 0.005$ & $0.003^{d} \pm 8 \star 10^{-4}$ & $1.6^{d} \pm 0.2$ & $1^{\mathrm{e}} \pm 0.2$ \\
\hline & $\begin{array}{l}0.1 \mu \mathrm{M} \\
\mathrm{MT}\end{array}$ & $0.03^{\mathrm{cd}} \pm 0.005$ & $0.004^{\mathrm{cd}} \pm 3^{\star} 10^{-4}$ & $1.76^{\mathrm{d}} \pm 0.6$ & $1^{e} \pm 0.5$ \\
\hline & $\begin{array}{l}10 \mu \mathrm{M} \\
\mathrm{MT}\end{array}$ & $0.03^{\mathrm{cd}} \pm 0.008$ & $0.005^{\mathrm{cd}} \pm 5^{\star} 10^{-5}$ & $1.96^{\mathrm{d}} \pm 0.8$ & $1^{e} \pm 0.9$ \\
\hline & $\begin{array}{l}15 \mu \mathrm{m} \\
\mathrm{MT}\end{array}$ & $0.03^{\mathrm{cd}} \pm 0.01$ & $0.003^{c d} \pm 9 * 10-4$ & $1.64^{d} \pm 0.08$ & $1^{e_{ \pm}} 0.1$ \\
\hline
\end{tabular}

Table 2: Effects of Melatonin and $\mathrm{NaCl}$ on Anthocyanin, Total Phenol, Flavonoid, PAL and TAL activity of alfalfa roots. Values express the means $\pm S D,(n=3)$ and according to Duncan's multiple range tests, letters indicate significant differences at $P<$ 0.05 . 


\begin{tabular}{|c|c|c|c|c|c|c|}
\hline Salt & Treatment & Anthocyanin $\left(\mu \mathrm{g} . \mathrm{g}^{-1} \mathrm{FW}\right)$ & $\begin{array}{l}\text { Total } \\
\text { Phenol }\left(\mathrm{mg} \cdot \mathrm{g}^{-1} \mathrm{FW}\right)\end{array}$ & Flavonoid(mg.g $\left.\mathrm{g}^{-1} \mathrm{FW}\right)$ & $\begin{array}{l}\text { PAL } \\
\text { activity } \\
\text { (nmol } \\
\text { Cinnamic } \\
\text { acid. } \mathrm{h}^{-1} \text {. } \\
\text { mg }^{-1} \\
\text { protein) }\end{array}$ & $\begin{array}{l}\text { TAL } \\
\text { activity } \\
\text { (nmol p- } \\
\text { coumaric } \\
\text { acid } \mathrm{h}^{-1} \text {. } \\
\mathrm{mg}^{-1} \\
\text { protein) }\end{array}$ \\
\hline \multirow{4}{*}{$\begin{array}{l}0 \\
\mathrm{mM} \\
\mathrm{NaCl}\end{array}$} & control & $3.44^{\mathrm{a}} \pm 0.2$ & $0.2^{c} \pm 0.01$ & $0.01^{\mathrm{c}} \pm 10^{-3}$ & $\begin{array}{l}45.4^{b} \pm \\
5.1\end{array}$ & $\begin{array}{l}31^{\mathrm{cd}} \pm \\
4.2^{2}\end{array}$ \\
\hline & $\begin{array}{l}0.1 \mu \mathrm{M} \\
\mathrm{MT}\end{array}$ & $3.84^{\mathrm{a}} \pm 0.2$ & $0.23^{\mathrm{b}} \pm 0.01$ & $0.02^{b} \pm 10^{-3}$ & $\begin{array}{l}52.43^{a} \pm \\
4\end{array}$ & $41^{\mathrm{a}} \pm 2.8$ \\
\hline & $\begin{array}{l}10 \mu \mathrm{M} \\
\mathrm{MT}\end{array}$ & $3.81^{\mathrm{a}} \pm 0.6$ & $0.25^{a} \pm 9 * 10^{-3}$ & $0.02^{b} \pm 10^{-3}$ & $\begin{array}{l}50.6^{\mathrm{a}} \\
\pm 0.9\end{array}$ & $\begin{array}{l}37.5^{\mathrm{ab}} \\
\pm 3.3\end{array}$ \\
\hline & $\begin{array}{l}15 \mu \mathrm{m} \\
\mathrm{MT}\end{array}$ & $4.17^{\mathrm{a}} \pm 0.3$ & $0.27^{\mathrm{a}} \pm 2 \star 10^{-3}$ & $0.02^{\mathrm{a}} \pm 10^{-3}$ & $\begin{array}{l}51.66^{\mathrm{a}} \pm \\
1.8\end{array}$ & $\begin{array}{l}40.43^{\mathrm{a}} \pm \\
1.7^{-}\end{array}$ \\
\hline \multirow{4}{*}{$\begin{array}{l}150 \\
\mathrm{mM} \\
\mathrm{NaCl}\end{array}$} & control & $3.34^{\mathrm{ab}} \pm 0.3$ & $0.13^{\mathrm{ef}} \pm 0.01$ & $0.01^{f} \pm 2 * 10^{-4}$ & $28.43^{\mathrm{ef}} \pm$ & $\begin{array}{l}20.8^{f} \pm \\
0.9\end{array}$ \\
\hline & $\begin{array}{l}0.1 \mu \mathrm{M} \\
\mathrm{MT}\end{array}$ & $2.87^{a b c} \pm 0.5$ & $0.15^{\mathrm{de}} \pm 3^{\star} 10^{-3}$ & $0.01^{e} \pm 10^{-4}$ & $\begin{array}{l}45.53^{f} \pm \\
1.1\end{array}$ & $\begin{array}{l}27.86^{\mathrm{de}} \pm \\
1.8\end{array}$ \\
\hline & $\begin{array}{l}10 \mu \mathrm{M} \\
\mathrm{MT}\end{array}$ & $3.47^{a} \pm 0.5$ & $0.16^{d} \pm 2 * 10^{-3}$ & $0.01^{d} \pm 4^{\star} 10^{-4}$ & $\begin{array}{l}35.5^{d} \pm \\
0.3^{-}\end{array}$ & $\begin{array}{l}35.46^{\mathrm{b}} \pm \\
3.1\end{array}$ \\
\hline & $\begin{array}{l}15 \mu \mathrm{m} \\
\mathrm{MT}\end{array}$ & $4^{\mathrm{a}} \pm 0.6$ & $0.16^{d} \pm 7 * 10^{-3}$ & $0.01^{\mathrm{cd}} \pm 6 * 10^{-4}$ & $\begin{array}{l}40.83^{c} \pm \\
\end{array}$ & $\begin{array}{l}34^{\mathrm{bc}} \pm \\
1.2\end{array}$ \\
\hline \multirow[t]{4}{*}{$\begin{array}{l}200 \\
\mathrm{mM} \\
\mathrm{NaCl}\end{array}$} & control & $1.68^{\mathrm{cd}} \pm 0.2$ & $0.1^{\mathrm{h}} \pm 0.01$ & $0.007^{i} \pm 3^{\star} 10^{-4}$ & $25^{f} \pm 0.1$ & $\begin{array}{l}15.83^{g} \pm \\
1.1\end{array}$ \\
\hline & $\begin{array}{l}0.1 \mu \mathrm{M} \\
\mathrm{MT}\end{array}$ & $1.28^{d} \pm 0.2$ & $0.11^{\mathrm{gh}} \pm 0.01$ & $0.009^{h} \pm 6 * 10^{-4}$ & $\begin{array}{l}18.46^{\mathrm{g}} \pm \\
1.6\end{array}$ & $\begin{array}{l}23.86^{\mathrm{ef}} \pm \\
1.4\end{array}$ \\
\hline & $\begin{array}{l}10 \mu \mathrm{M} \\
\mathrm{MT}\end{array}$ & $1.71^{\mathrm{cd}} \pm 0.4$ & $0.12^{f g} \pm 3^{*} 10^{-3}$ & $0.009^{g h} \pm 9 * 10^{-4}$ & $\begin{array}{l}25.76^{\mathrm{ef}} \pm \\
1.6\end{array}$ & $\begin{array}{l}22.8^{f} \pm \\
2.1\end{array}$ \\
\hline & $\begin{array}{l}15 \mu \mathrm{m} \\
\mathrm{MT}\end{array}$ & $2^{b c d} \pm 0.3$ & $0.12^{f g} \pm 4^{\star} 10^{-4}$ & $0.01^{g} \pm 8 * 10^{-4}$ & $\begin{array}{l}29.36^{\mathrm{e}} \pm \\
1.6\end{array}$ & $24.4^{\mathrm{ef}} \pm$ \\
\hline
\end{tabular}

Table 3: Effects of Melatonin and $\mathrm{NaCl}$ on Electrolyte leakage, MDA, ROS, $\mathrm{H}_{2} \mathrm{O}_{2}$ and $\mathrm{O}^{2-}$ of alfalfa root. Values express the means $\pm S D,(n=3)$ and according to Duncan's multiple range tests, letters indicate significant differences at $P<0.05$. 


\begin{tabular}{|c|c|c|c|c|c|c|}
\hline Salt & Treatment & $\operatorname{MDA}\left(\mu \mathrm{M} \cdot \mathrm{g}^{-1} \mathrm{FW}\right)$ & EL (\%) & ROS(RFU.mg ${ }^{-1}$ Protein) & $\mathrm{H}_{2} \mathrm{O}_{2}\left(\mu \mathrm{M} \cdot \mathrm{g}^{-1} \mathrm{FW}\right)$ & $\mathrm{O}^{2-}\left(\mathrm{OD} \cdot \mathrm{g}^{-1} \mathrm{FW}\right)$ \\
\hline \multirow[t]{4}{*}{$0 \mathrm{mM} \mathrm{NaCl}$} & control & $7.8^{c} \pm 0.5$ & $\begin{array}{l}18.4^{\mathrm{e}_{ \pm}} \\
0.9^{-}\end{array}$ & $1.5^{\mathrm{de}_{ \pm}} 3^{*} 10^{-4}$ & $0.7^{\text {bcde }_{ \pm} 0.1}$ & $1.8^{e_{ \pm}} 0.02$ \\
\hline & $\begin{array}{l}0.1 \mu \mathrm{M} \\
\mathrm{MT}\end{array}$ & $7.6^{c} \pm 0.3$ & $\begin{array}{l}18.9^{\mathrm{e}_{ \pm}} \\
2.3^{-}\end{array}$ & $1.2^{\mathrm{e}} \pm 10^{-4}$ & $0.2^{\mathrm{e}_{ \pm}} 0.07$ & $1.7^{\mathrm{e}_{ \pm}} 0.01$ \\
\hline & $10 \mu \mathrm{M}$ MT & $8.4^{b c} \pm 1.5$ & $\begin{array}{l}18.3^{\mathrm{e}_{ \pm}} \\
3.5\end{array}$ & $1^{\mathrm{e}} \pm 2 \star 10^{-4}$ & $0.4^{\mathrm{de}_{ \pm 0}} .1$ & $1.7^{\mathrm{e}} \pm 0.01$ \\
\hline & $15 \mu \mathrm{m}$ MT & $7.2^{c} \pm 1.7$ & $\begin{array}{l}18.6^{\mathrm{e}_{ \pm}} \\
0.4\end{array}$ & $1.1^{\mathrm{e}_{ \pm}} \pm 6^{*} 10^{-4}$ & $0.3^{e_{ \pm}} 0.2$ & $1.7^{e_{ \pm}} 0.01$ \\
\hline \multirow[t]{4}{*}{$\begin{array}{l}150 \mathrm{mM} \\
\mathrm{NaCl}\end{array}$} & control & $12^{\mathrm{ab}} \pm 1.2$ & $\begin{array}{l}40.2^{\mathrm{c}} \pm \\
2.4^{-}\end{array}$ & $3.3^{\mathrm{ab}} \pm 10^{-4}$ & $1^{\mathrm{ab}} \pm 0.1$ & $4.3^{b} \pm 0.02$ \\
\hline & $\begin{array}{l}0.1 \mu \mathrm{M} \\
\mathrm{MT}\end{array}$ & $7.8^{c} \pm 1.9$ & $\begin{array}{l}30.2^{d_{ \pm}} \\
1.2^{2}\end{array}$ & $2.3^{\mathrm{c}} \pm 10^{-4}$ & $0.3^{e_{ \pm}} 0.1$ & $2.1^{d} \pm 0.01$ \\
\hline & $10 \mu \mathrm{M} \mathrm{MT}$ & $8.4^{\mathrm{bc}} \pm 0.8$ & $34^{d} \pm 0.2$ & $1.9^{\mathrm{cd}} \pm 3 * 10^{-4}$ & $0.5^{\mathrm{cde}_{ \pm}} 0.1$ & $3^{c} \pm 0.05$ \\
\hline & $15 \mu \mathrm{m} \mathrm{MT}$ & $10.2^{b c} \pm 0.3$ & $\begin{array}{l}30.2^{d_{ \pm}} \\
1.7^{-}\end{array}$ & $2^{\mathrm{cd}} \pm 7 * 10^{-4}$ & $0.6^{\mathrm{cde}_{ \pm} 0.08}$ & $2.7^{c d} \pm 0.01$ \\
\hline \multirow[t]{4}{*}{$\begin{array}{l}200 \mathrm{mM} \\
\mathrm{NaCl}\end{array}$} & control & $14.6^{\mathrm{a}} \pm 2$ & $\begin{array}{l}56.4^{\mathrm{a}} \pm \\
7.8\end{array}$ & $4.3^{\mathrm{a}} \pm 10^{-4}$ & $1.2^{\mathrm{a}} \pm 0.1$ & $5.5^{\mathrm{a}} \pm 0.03$ \\
\hline & $\begin{array}{l}0.1 \mu \mathrm{M} \\
\mathrm{MT}\end{array}$ & $10.2^{b c_{ \pm}} 1.3$ & $49^{b} \pm 1.6$ & $2.2^{\mathrm{bc}} \pm 10^{-4}$ & $0.8^{\mathrm{bcd}} \pm 0.1$ & $2.9^{c} \pm 0.02$ \\
\hline & $10 \mu \mathrm{M} \mathrm{MT}$ & $8^{d} \pm 2.3$ & $\begin{array}{l}40.1^{c} \pm \\
1.7^{c}\end{array}$ & $2.4^{\mathrm{cd}} \pm 4 * 10^{-4}$ & $0.9^{b c} \pm 0.1$ & $4^{b c} \pm 0.01$ \\
\hline & $15 \mu \mathrm{m}$ MT & $9.5^{\mathrm{bc}} \pm 1.7$ & $\begin{array}{l}45.5^{\mathrm{b} \pm} \\
1.1\end{array}$ & $2.7^{\mathrm{bc}} \pm 4^{\star} 10^{-4}$ & $1^{\mathrm{bc}} \pm 0.1$ & $2.9^{c} \pm 0.01$ \\
\hline
\end{tabular}

\section{Figures}


(A)

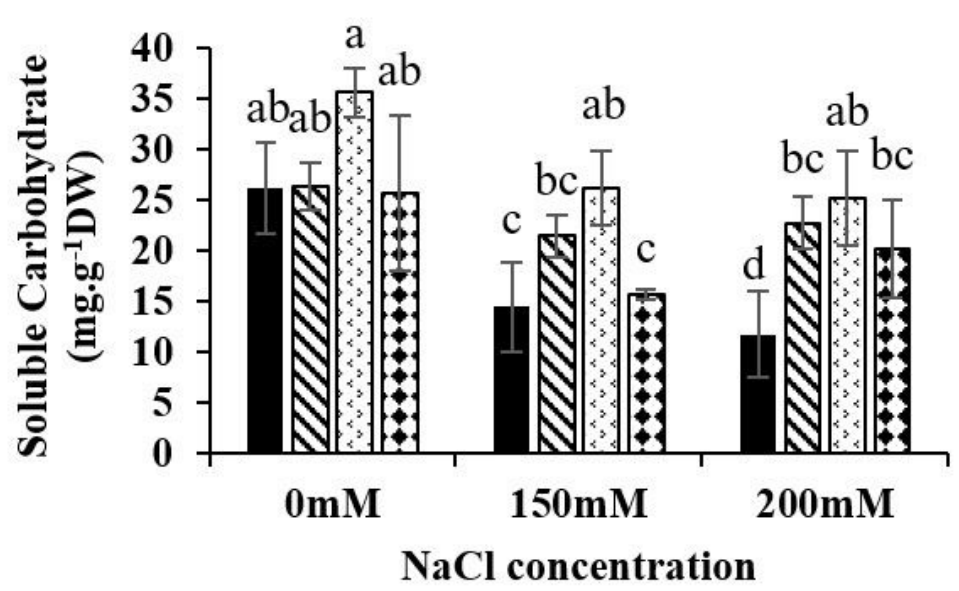

(B)

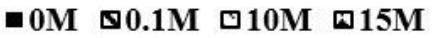

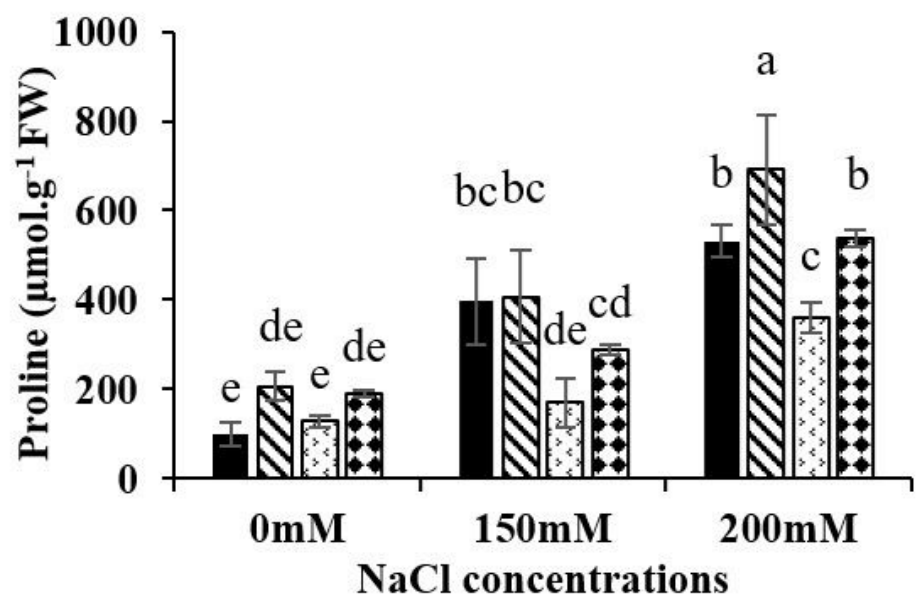

(C)

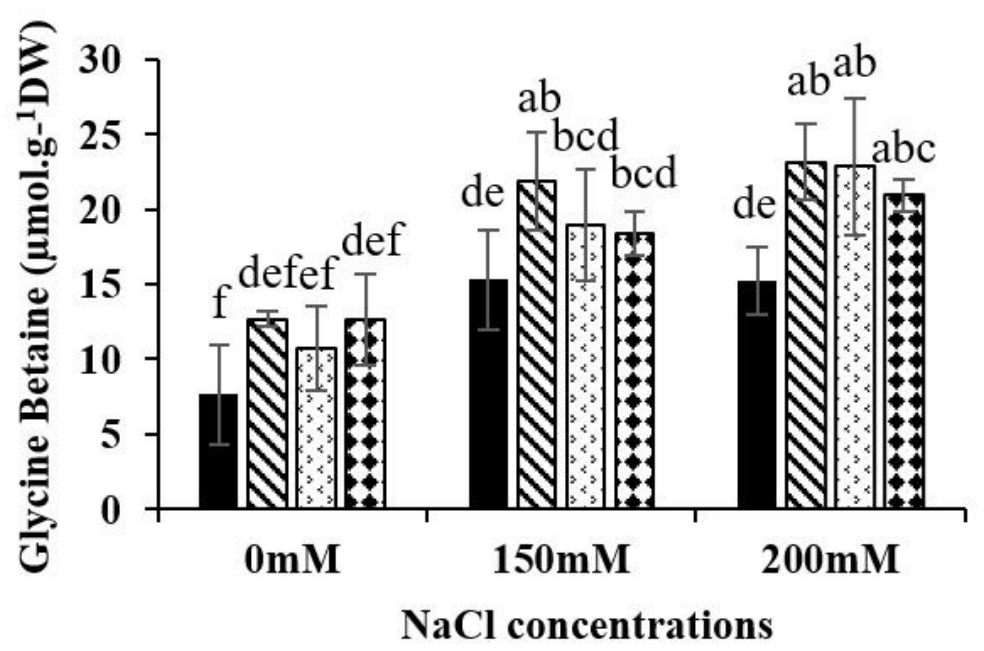

Figure 1

Effects of Melatonin and $\mathrm{NaCl}$ on Soluble Carbohydrate (A), Proline (B) and Glycine betaine (C) of alfalfa root. Data are means of three replicates \pm SD. Different letters indicate significant differences $(P<0.05)$ based on Duncan's multiple range test 
(A) $0 \mathrm{mM} \mathrm{NaCL} 150 \mathrm{mM}$ NaCl $200 \mathrm{mM} \mathrm{NaCl}$

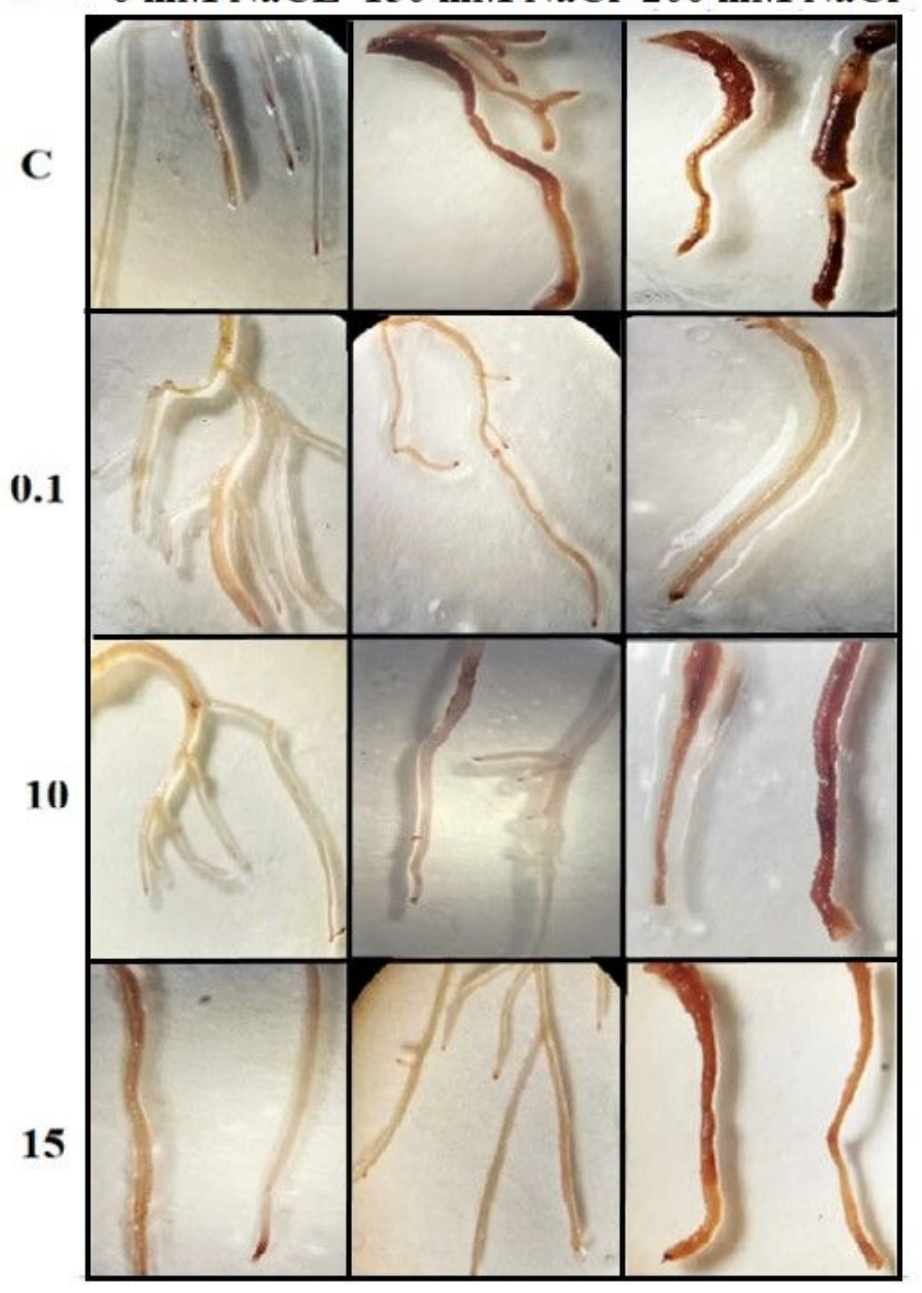

(B) $0 \mathrm{mM} \mathrm{NaCL} 150 \mathrm{mM} \mathrm{NaCl} 200 \mathrm{mM} \mathrm{NaCl}$

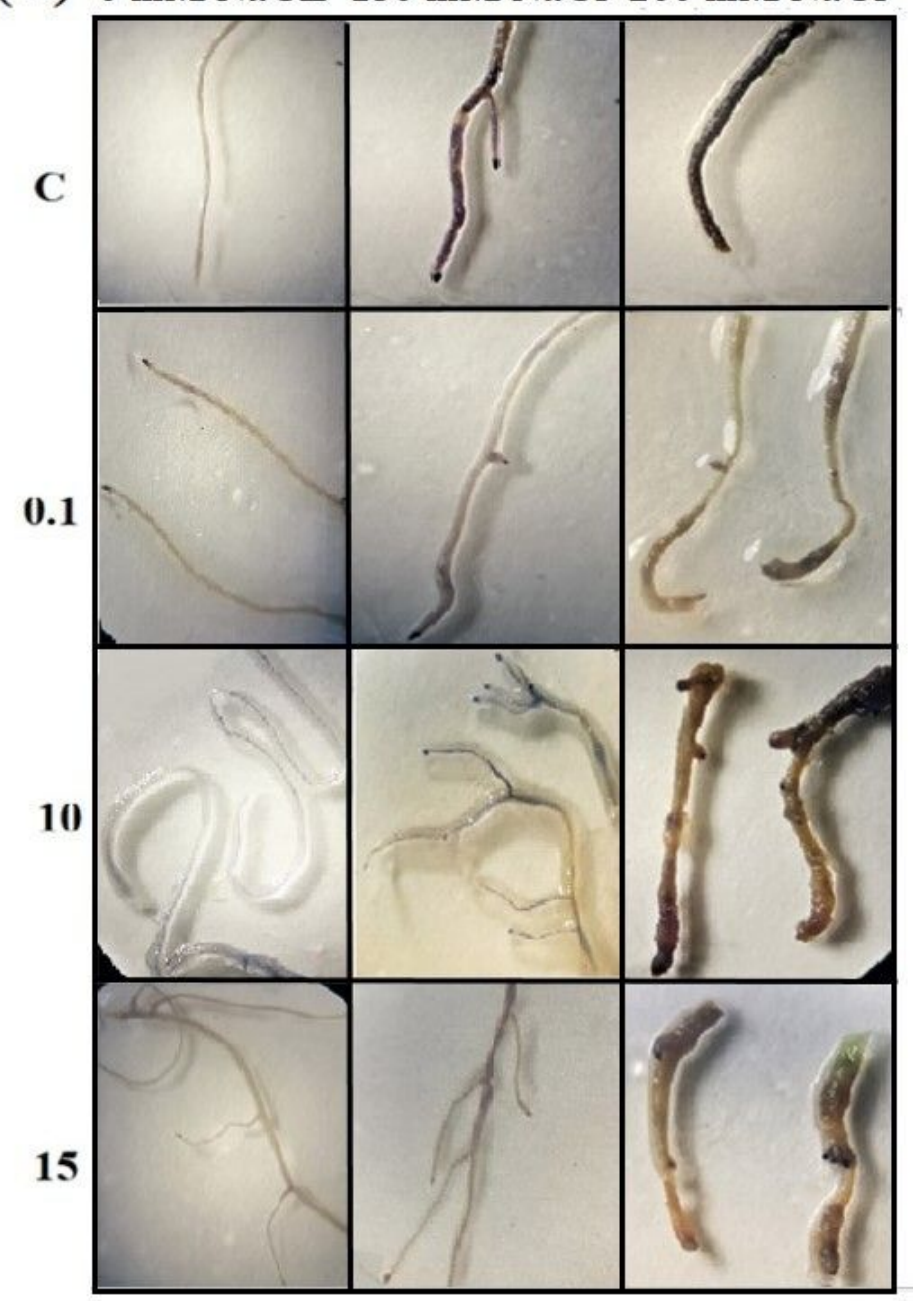

Figure 2

Histochemical staining of ROS accumulations using DAB (A) and NBT (B) for investigated the effect of $0.1 \mu \mathrm{M}, 10 \mu \mathrm{M}$ and $15 \mu \mathrm{M}$ melatonin on $\mathrm{H} 2 \mathrm{O} 2$ and 02 - content in alfalfa root 
(A)

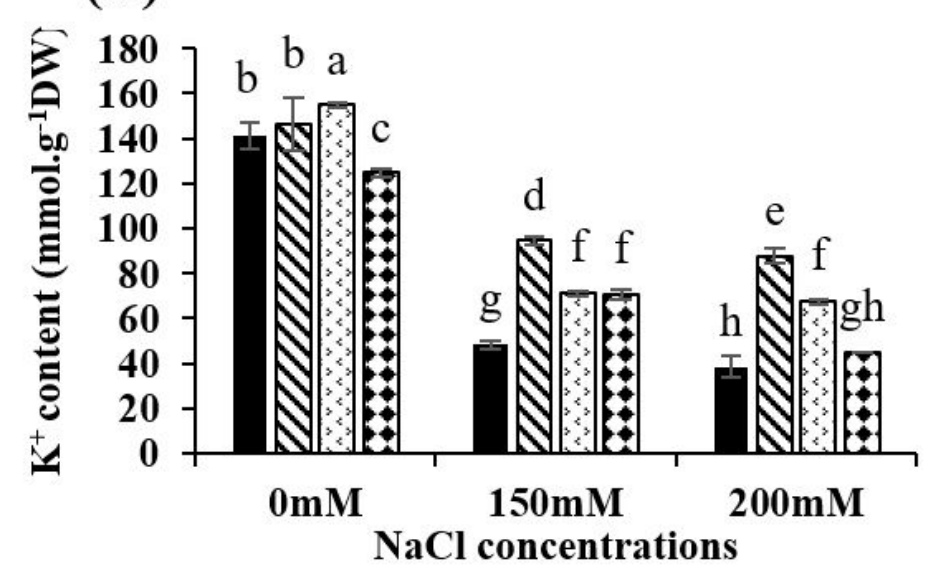

(B)

$\square 0 \mathrm{M} \mathbf{0 . 1 M} \square 10 \mathrm{M} \otimes 15 \mathrm{M}$

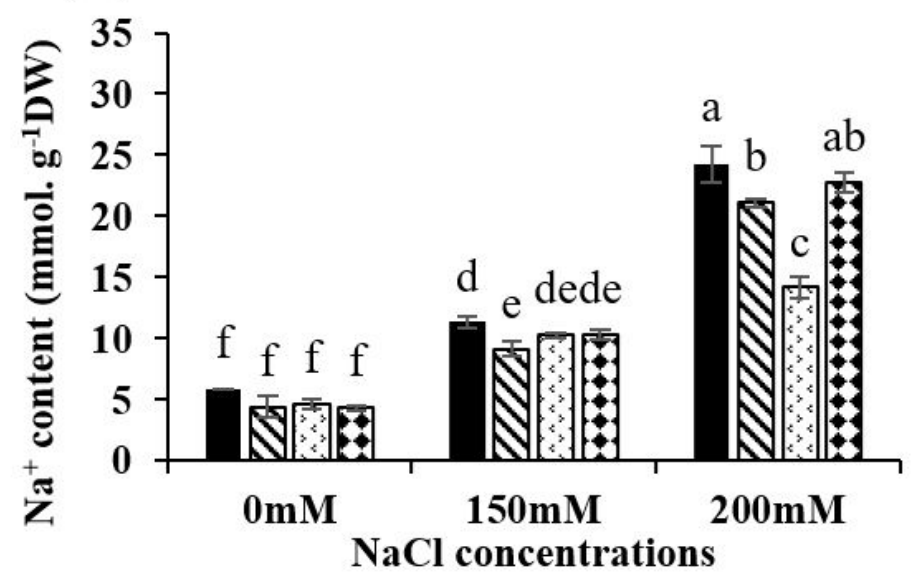

(C)

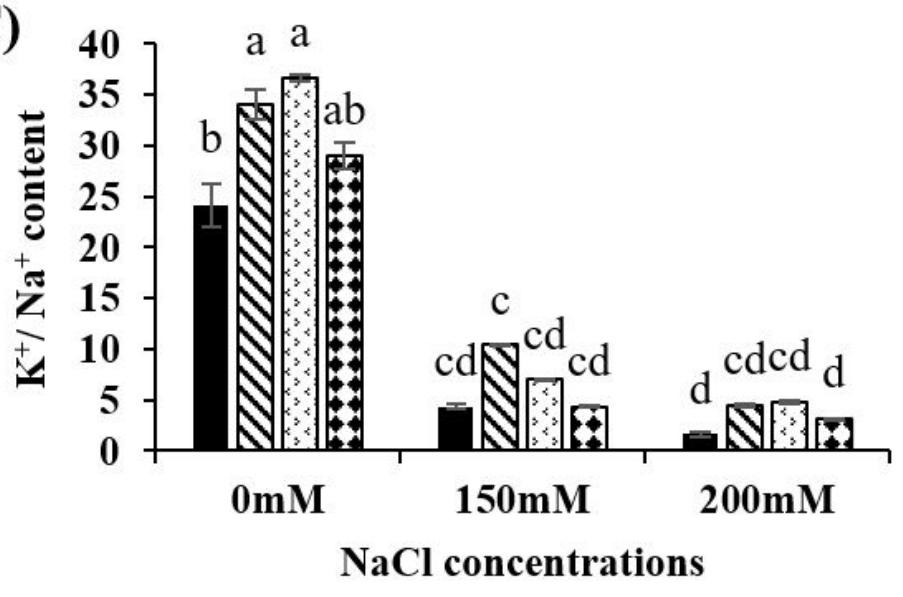

Figure 3

Effects of Melatonin and $\mathrm{NaCl}$ on $\mathrm{K}+(\mathrm{A}), \mathrm{Na}+(\mathrm{B})$ and $\mathrm{K}+/ \mathrm{Na}+(\mathrm{C})$ content of alfalfa root. Data are means of three replicates $\pm S D$. Different letters indicate significant differences $(P<0.05)$ based on Duncan's multiple range test 
A
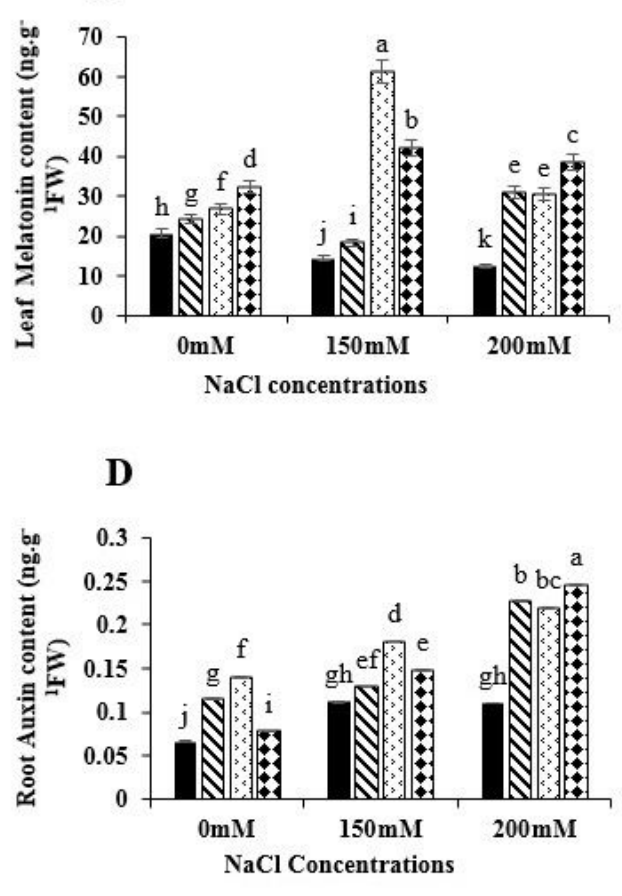

B



E

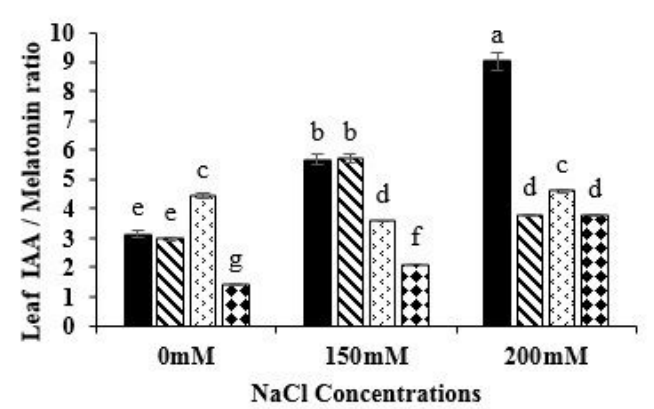

C
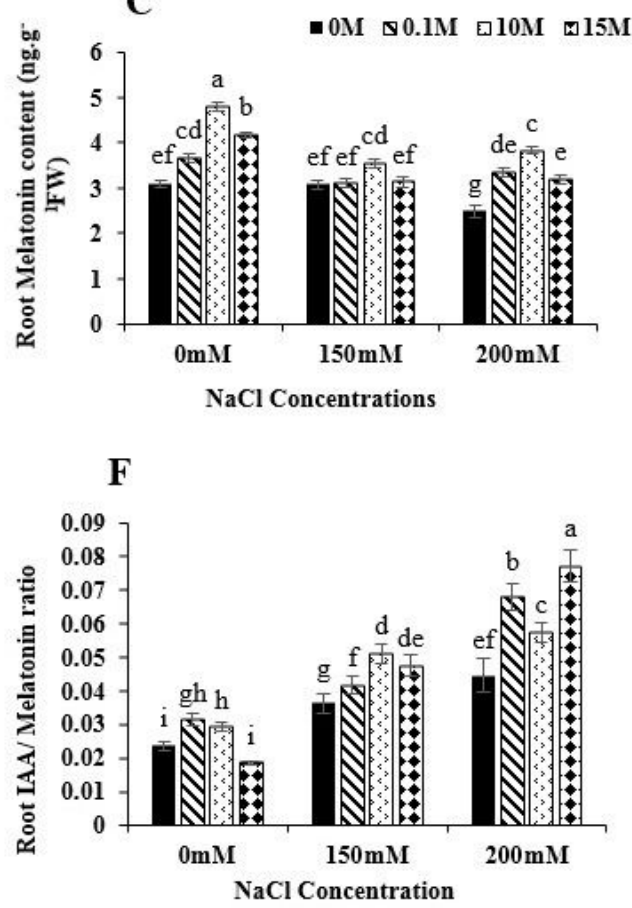

Figure 4

Effects of Melatonin and $\mathrm{NaCl}$ treatment on Leaf Melatonin content (A), Leaf Auxin content (B), Root Melatonin content (C), Root Auxin content (D), Leaf IAA / Melatonin ratio (E) and Root IAA / Melatonin ratio (F) of alfalfa. Data are means of three replications \pm SD. Different letters indicate significant differences $(P<0.05)$ based on Duncan's multiple range test 

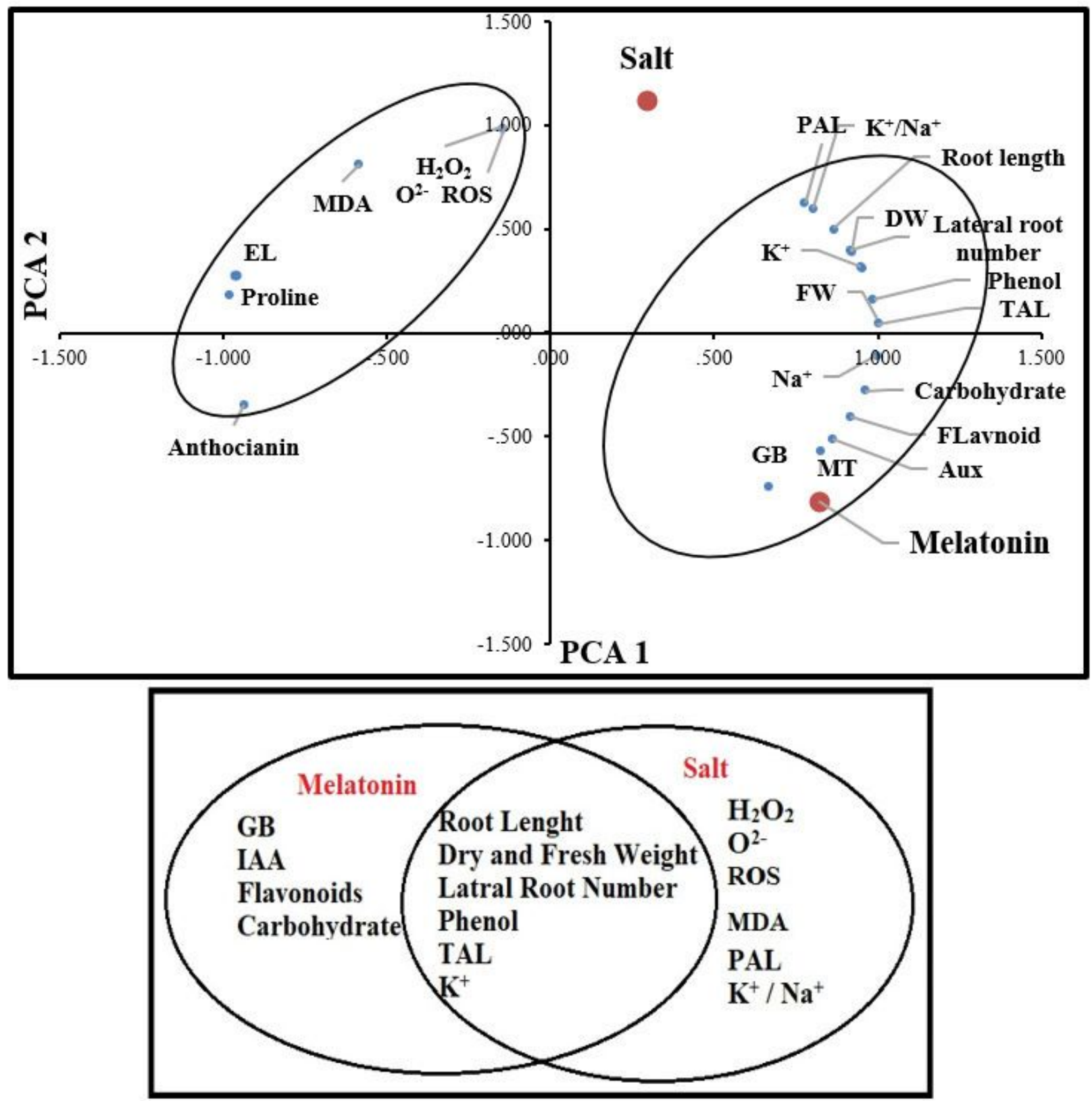

Figure 5

Result of biplot Principal Components 1 and 2 analyses in alfalfa root subjected to melatonin and salinity (A), and the main objectives (B) 